\title{
Bacteriocins from the rhizosphere microbiome - from an agriculture perspective
}

\author{
Sowmyalakshmi Subramanian and Donald L. Smith* \\ Department of Plant Sciences, Macdonald Campus/McGill University, Sainte-Anne-de-Bellevue, QC, Canada
}

Bacteria produce and excrete a versatile and dynamic suit of compounds to defend against microbial competitors and mediate local population dynamics. These include a wide range of broad-spectrum non-ribosomally synthesized antibiotics, lytic enzymes, metabolic by-products, proteinaceous exotoxins, and ribosomally produced antimicrobial peptides (bacteriocins). Most bacteria produce at least one bacteriocin. Bacteriocins are of interest in the food industry as natural preservatives and in the probiotics industry, leading to extensive studies on lactic acid bacteria (colicin produced by Escherichia coli is a model bacteriocin). Recent studies have projected use of bacteriocins in veterinary medicine and in agriculture, as biostimulants of plant growth and development and as biocontrol agents. For example, bacteriocins such as Cerein 8A, Bac-GM17, putidacin, Bac 14B, amylocyclicin have been studied for their mechanisms of anti-microbial activity. Bac $\mathbb{H} 7$ promotes tomato and musk melon plant growth. Thuricin 17 (Th17) is the only bacteriocin studied extensively for plant growth promotion, including at the molecular level. Th17 functions as a bacterial signal compound, promoting plant growth in legumes and non-legumes. In Arabidopsis thaliana and Glycine max Th17 increased phytohormones IAA and $\mathrm{SA}$ at $24 \mathrm{~h}$ post treatment. At the proteome level Th17 treatment of 3-weekold $A$. thaliana rosettes led to $>2$-fold changes in activation of the carbon and energy metabolism pathway proteins, $24 \mathrm{~h}$ post treatment. At $250 \mathrm{mM} \mathrm{NaCl}$ stress, the control plants under osmotic-shock shut down most of carbon-metabolism and activated energy-metabolism and antioxidant pathways. Th17 treated plants, at $250 \mathrm{mM} \mathrm{NaCl}$, retained meaningful levels of the light harvesting complex, photosystems I and II proteins and energy and antioxidant pathways were activated, so that rosettes could better withstand the salt stress. In Glycine max, Th17 helped seeds germinate in the presence of $\mathrm{NaCl}$ stress, and was most effective at $100 \mathrm{mM} \mathrm{NaCl}$. The $48 \mathrm{~h}$ post germination proteome suggested efficient and speedier partitioning of storage proteins, activation of carbon, nitrogen and energy metabolisms in Th17 treated seeds both under optimal and $100 \mathrm{mM} \mathrm{NaCl}$. This review focuses on the bacteriocins produced by plant-rhizosphere colonizers and plant-pathogenic bacteria, that might have uses in agriculture, veterinary, and human medicine.

Keywords: Bacillus species, Bacillus thuringiensis, bacteriocins, anti-microbial peptides 


\section{INTRODUCTION TO BACTERIOCINS}

Microbial population dynamics are primarily controlled by the products bacteria produce and excrete into their environs. This versatile and a dynamic suit of compounds order the defense mechanisms, rightly described as "a never ending arms race" (Riley, 1998) against microbial competitors and also as signaling compounds for plant colonization in a given soil. The excreted bacterial compounds we recognize now include a wide range of broad-spectrum non-ribosomally synthesized antibiotics, lytic enzymes (lysozymes), metabolic by-products such as organic acids, proteinaceous exotoxins, and chromosomally and/or ribosomally produced antimicrobial peptides, referred to as bacteriocins that are of particular importance in bacterial defense. It is supposed that most bacteria produce at least one bacteriocin.

Bacteriocins are extracellular substances produced by bacteria having distinctive morphological and biochemical characteristics, ranging from a very low to high molecular weight complexes, wherein the activity is predominantly associated with a protein. They are mostly synthesized from plasmids, but many are of chromosomal origin as well and are synthesized at various stages of bacterial growth and under various environmental conditions (Daw and Falkiner, 1996); they affect the growth of related bacterial species. Bacteriocins are grouped into four distinct classes based on peptide characteristics such as post translational modifications, side chains, heat stability, $\mathrm{N}$-terminal sequence homology, and molecular weight (Klaenhammer, 1993). Bacillus species were first reported to produce bacteriocins in 1976 and the diversity of these is well described in the review by Abriouel et al. (2011). The low-molecular-weight bacteriocins of the Gram-positive bacteria were reported to demonstrate bactericidal activity, mainly against certain other Gram-positive bacteria (Tagg et al., 1976). The most studied bacteriocin is colicin of the Enterobacteriaceae (Pugsley, 1984). Due to their commercial importance as natural preservatives, and as therapeutic agents against pathogenic bacteria, these antimicrobial peptides have been a major area of scientific research (Tagg et al., 1976; Jack et al., 1995; de la Fuente-Salcido et al., 2013). Nisin, synthesized by Lactococcus lactis, is the only bacteriocin generally regarded as safe for human consumption (GRAS) but has limited usage since it is ineffective against Gram-negative bacteria (Olasupo et al., 2003) necessitating exploration of newer bacteriocins. Hence, this review is an update regarding the bacteriocins produced by plantrhizosphere colonizers and those from plant-pathogenic bacteria that might have uses in agriculture and veterinary or human medicine.

\section{BACTERIOCINS FROM RHIZOSPHERE BACTERIA}

The bacteriocin cerein7, from Bacillus cereus with a mass of $3.94 \mathrm{kDa}$ was the first to be isolated from this species (Oscáriz et al., 1999) although other bacillus species such as B. thuringiensis, B. subtilis, B. stearothermophilus, B. licheniformis, $B$. megaterium, and B. cereus were reported earlier to produce bacteriocin like products, of which subtilin from $B$. subtilis has been studied widely. The earliest studies of bacteriocin mode of action focused on Rhizobium lupini isolated from root nodules of lupines that harbor two strains of the species 16-2 and 16-3, the latter of which produces a bacteriocin to inhibit the growth of its closely associated 16-2 strain (Lotz and Mayer, 1972). A comparison of these two strains revealed that bacteriocin activity of one bacteria can be neutralized by lipopolysaccharides of other associated bacteria, by micellar modulation of LPS for bacteriocin adsorption. This bacteriocin neutralizing activity, as seen in bacteriocin sensitive $R$. lupini 16-2 (Pfister and Lodderstaedt, 1977), leads one to wonder why certain bacteria are able to adapt and colonize plant roots more effectively, despite their sensitivity to bacteriocins. Now we are aware that bacteriocin resistance can be innate or acquired and this varies across strains of the same bacterial species. In general changes to the bacterial cell wall resulting in loss of bacteriocin insertion or binding regions, sequestration of bacteriocins, export or degradation of bacteriocins have been adopted by Gram-positive bacteria (de Freire Bastos et al., 2015).

Cerein $8 \mathrm{~A}$ isolated from $B$. cereus $8 \mathrm{~A}$, interferes with cell membrane integrity and causes cell wall damage (Bizani et al., 2005), which is seen to be the mode of action of many bacteriocins. (Please refer to Table 1 for bacteriocins from B. thuringiensis and examples of other bacteria). Bacteriocin Bac-GM17 from the rhizosphere bacteria Bacillus clausii strain GM17 of Ononis angustissima Lam. is a $5.158 \mathrm{kDa}$ monomer protein with a unique sequence and having bactericidal effect on Agrobacterium tumefaciens C58 and fungistatic effect on Candida tropicalis R2 CIP203 (Mouloud et al., 2013). The bacteriocin putidacin, produced by Pseudomonas putida strain BW11M1, isolated from banana root, is very similar to mannosebinding plant lectins (Parret et al., 2003). Amylocyclicin, a $6.381 \mathrm{kDa}$ peptide from Bacillus amyloliquefaciens FZB42, is a novel circular, ribosomally synthesized bacteriocin with high antibacterial activity to closely related Gram-positive bacteria (Scholz et al., 2014). B. subtilis strain 14B produces Bac 14B, a $21 \mathrm{kDa}$ bacteriocin that is effective against crown gall disease caused by A. tumefaciens (Hammami et al., 2009). B. subtilis strain IH7 produces a bacteriocin Bac IH7 which is reported to be a plant growth promotor. Tomato and muskmelon treated with Bac IH7 showed enhanced germination percentage and increased shoot weight and height and root lengths; it also served as a biocontrol for Alternaria solani and other seed borne pathogens (Hammami et al., 2011). A 25-35 kDa bacteriocin from Lysinibacillus jx416856, a bacteria isolated from fruit and vegetable waste, was observed to inhibit food borne pathogens such as Staphylococcus aureus, Staphylococcus epidermidis, and B. cereus (Ahmad et al., 2014).

Some plant pathogens have also been found to produce bacteriocins. Phytopathogenic strain Erwinia carotovora NA4, isolated from diseased fruits and vegetables, produces the bacteriocin erwiniocin NA4 and Agrobacterium radiobacter NA5 (pepper rhizosphere isolate) produces agrocin NA5 (Jabeen et al., 2004). Tomato pathogen Clavibacter michiganensis ssp. michiganensis produces a bacteriocin michiganin $\mathrm{A}$, which inhibits the growth of another pathogen C. michiganensis subsp. 
sepedonicus, which causes ring rot of potatoes. This bacteriocin also has similarity to a type B lantibiotic produced by the actinomycete Actinoplanes liguriae (Holtsmark et al., 2006). Pseudomonas syringae pv. syringae produces S-type pyocins (Feil et al., 2005), which are also produced by the opportunistic human pathogen Pseudomonas aeruginosa. Carocin S1, is a $55 \mathrm{kDa}$ bacteriocin from Pectobacterium carotovorum (previously known as E. carotovora ssp. carotovora; Holtsmark et al., 2008).

Bacillus thuringiensis is the most studied Bacillus species due to its interesting array of excreted proteins. B. thuringiensis is a Gram-positive spore-forming bacterium characterized and distinguished from closely related Bacillus species by its ability to synthesize characteristic endotoxins that are active against diptera, coleoptera, and Lepidoptera larvae (Schnepf et al., 1998; Palma et al., 2014). Widely used as a bioinsecticide, it also accounts for about $90 \%$ of the commercially available biopesticides produced (Chattopadhyay et al., 2004), apart from the $\mathrm{Bt}$ genes incorporation in several commercial crops, the proteomics and genomics of which is well known (Ibrahim et al., 2010; de la Fuente-Salcido et al., 2013). B. thuringiensis was discovered as early as 1901 in Japan by bacteriologist S. Ishiwata as an isolate from diseased Bombyx mori (L.) larvae and was named Sottokin meaning "Sudden death bacillus". A similar study by Ernst Berliner, described B. thuringiensis as the causal organism of insect death isolated from Anagasta kuehniella (Zeller) larvae from Thuringia, Germany in 1915 [Beegle and Yamamoto, 1992 (a very good review for the history of B. thuringiensis)].

Bacillus thuringiensis strains have been found to produce bacteriocins such as thuricin (>950 kDa; Favret and Yousten, 1989), tochicin (10.5 kDa; Paik et al., 1997), thuricin 7 (11.6 kDa; Cherif et al., 2001), thuricin 439A and thuricin 439B (2.9 and $2.8 \mathrm{kDa}$, respectively; Ahern et al., 2003), entomocin 9 (Cherif et al., 2003), bacthuricin F4 (3.160 kDa; Kamoun et al., 2005), thuricin 17 (3.162 kDa; Gray et al., 2006b), etc. A comprehensive list of known bacteriocins is provided in Table 1. New bacteriocins are being discovered regularly. Raddadi et al., (2009) evaluated 16 strains of $B$. thuringiensis for their capability to protect plants from phytopathogens. Among them, Bt HD868 tochigiensis and Bt HD9 entomocidus strains were observed to be the least cytotoxic, and hence potentially acceptable for the food industry and field crop application for protection against deleterious bacteria. This compatibility was based on the levels of autolysins, bacteriocins and AHL-lactonases, and antibiotic Zwittermicin A activities. Further these strains were also active against fungal diseases caused by Aspergillus niger, Aspergillus fumigatus, Aspergillus flavus, Cryphonectria parasitica, Fusarium oxysporum, Monilia sitophila, Monilia hiemalis, Penicillium digitatum, and Rhizopus sp. (Raddadi et al., 2009). While many B. thuringiensis strains have been identified and bacteriocins were isolated and characterized to an extent, none of these bacteriocins have been studied for plant growth promotion as extensively as thuricin 17 from $B$. thuringiensis NEB17.

Bacillus thuringiensis NEB17 was isolated from soybean root nodules as putative endophytic bacteria in 1998 in Prof. Donald Smith's laboratory at McGill University. When co-inoculated
TABLE 1 | Bacteriocins identified from Bacillus thuringiensis and examples of other bacteriocin producers.

\begin{tabular}{|c|c|c|c|}
\hline $\begin{array}{l}\text { Bacillus } \\
\text { thuringiensis } \\
\text { strain }\end{array}$ & $\begin{array}{l}\text { Name of } \\
\text { Bacteriocin } \\
\text { identified }\end{array}$ & $\begin{array}{l}\text { Molecular } \\
\text { weight }\end{array}$ & Reference \\
\hline HD-2 & Thuricin & >950 Da & $\begin{array}{l}\text { Favret and Yousten, } \\
1989\end{array}$ \\
\hline $\begin{array}{l}\text { ssp. tochigiensis } \\
\text { HD868 }\end{array}$ & Tochicin & $10.5 \mathrm{kDa}$ & Paik et al., 1997 \\
\hline BMG1.7 & Thuricin 7 & $11.6 \mathrm{kDa}$ & Cherif et al., 2001 \\
\hline B439 & Thuricin 439 & $3 \mathrm{kDa}$ & Ahern et al., 2003 \\
\hline $\begin{array}{l}\text { ssp. entomocidus } \\
\text { HD9 }\end{array}$ & Entomocin 9 & $12.4 \mathrm{kDa}$ & Cherif et al., 2003 \\
\hline BUPM4 & Bacthuricin F4 & $3.1 \mathrm{kDa}$ & $\begin{array}{l}\text { Kamoun et al., } \\
2005\end{array}$ \\
\hline NEB17 & Thuricin 17 & $3.16 \mathrm{kDa}$ & Gray et al., 2006b \\
\hline $\begin{array}{l}\text { ssp. entomocidus } \\
\text { HD110 }\end{array}$ & Entomocin 110 & $4.8 \mathrm{kDa}$ & Cherif et al., 2008 \\
\hline $\begin{array}{l}\text { ssp. entomocidus } \\
\text { HD198 }\end{array}$ & Thuricin S & $3.1 \mathrm{kDa}$ & $\begin{array}{l}\text { Chehimi et al., } \\
2007\end{array}$ \\
\hline $\begin{array}{l}\text { ssp. morrisoni } \\
\text { (LBIT } 269\end{array}$ & Morricin 269 & $10 \mathrm{kDa}$ & $\begin{array}{l}\text { Barboza-Corona } \\
\text { et al., 2007; de la } \\
\text { Fuente-Salcido } \\
\text { et al., } 2008\end{array}$ \\
\hline $\begin{array}{l}\text { ssp. kurstaki (LBIT } \\
\text { 287) }\end{array}$ & Kurstacin 287 & $10 \mathrm{kDa}$ & $\begin{array}{l}\text { Barboza-Corona } \\
\text { et al., 2007; de la } \\
\text { Fuente-Salcido } \\
\text { et al., } 2008\end{array}$ \\
\hline $\begin{array}{l}\text { ssp. kenyae (LBIT } \\
\text { 404) }\end{array}$ & Kenyacin 404 & $10 \mathrm{kDa}$ & $\begin{array}{l}\text { Barboza-Corona } \\
\text { et al., 2007; de la } \\
\text { Fuente-Salcido } \\
\text { et al., } 2008\end{array}$ \\
\hline $\begin{array}{l}\text { ssp. entomocidus } \\
\text { (LBIT 420) }\end{array}$ & Entomocin 420 & $10 \mathrm{kDa}$ & $\begin{array}{l}\text { Barboza-Corona } \\
\text { et al., 2007; de la } \\
\text { Fuente-Salcido } \\
\text { et al., } 2008\end{array}$ \\
\hline $\begin{array}{l}\text { ssp. tolworthi (LBIT } \\
\text { 524) }\end{array}$ & Tolworthcin 524 & $10 \mathrm{kDa}$ & $\begin{array}{l}\text { Barboza-Corona } \\
\text { et al., 2007; de la } \\
\text { Fuente-Salcido } \\
\text { et al., } 2008\end{array}$ \\
\hline $\begin{array}{l}\text { SF361 [isolated } \\
\text { from honey] }\end{array}$ & Thuricin $\mathrm{H}$ & $3.1 \mathrm{kDa}$ & Lee et al., 2009a \\
\hline DPC6431 & Thuricin CD & $\begin{array}{l}2.763 / \\
2.861 \mathrm{kDa}\end{array}$ & Rea et al., 2010 \\
\hline BUPM103 & Bacthuricin F103 & $11 \mathrm{kDa}$ & $\begin{array}{l}\text { Kamoun et al., } \\
2011\end{array}$ \\
\hline ssp. kurstaki Bn1 & $\mathrm{Bn} 1$ & 3.193 kDa & Ugras et al., 2013 \\
\hline
\end{tabular}

[isolated from a

Hazel nut pest]

Examples from Bacillus and other bacterial species

Cerein 7

$3.94 \mathrm{kDa}$

Pseudomonas

Putidacin

Oscáriz et al., 1999 putida BW11M1

Bacillus cereus $8 \mathrm{~A}$

Cerein 8A

Clavibacter

Michiganin A

michiganensis ssp.

michiganensis

Bacillus

BL8

licheniformis

Bac GM17

Bacillus clausii
Parret et al., 2003

Bizani et al., 2005

Holtsmark et al., 2006

Smitha and Bhat, 2012

Mouloud et al., 2013 
with Bradyrhizobium japonicum under nitrogen free conditions, this bacterium promoted soybean growth, nodulation, and grain yield (Bai et al., 2002b, 2003). Subsequently, the causative agent of plant growth promotion, a bacteriocin, was isolated from $B$. thuringiensis NEB17, and is now referred to as thuricin 17 (Gray et al., 2006b). Initially, its partial sequence was determined (Gray et al., 2006a), and its full sequence has since reported (Lee et al., 2009b). Thuricin 17 is a low molecular weight peptide of $3.162 \mathrm{kDa}$, stable across a $\mathrm{pH}$ range of $1.0-9.25$, highly heat resistant and is inactivated by treatment with proteolytic enzymes. Based on its N-terminal sequence homology of Th17 and that of bacthuricin F4, a new class of bacteriocins, class IId was proposed (Gray et al., 2006b). The bacteriocins produced by $B$. thuringiensis strain NEB17 (Th17) and B. thuringiensis ssp. kurstaki BUPM4 (bacthuricin F4 - 3160.05 Da) have been reported to show functional similarities and anti-microbial activities (Jung et al., 2008a).

In addition, Th17, applied as leaf spray and root drench, has positive effects on soybean and corn and stimulated plant growth. The leaves of 2-week-old soybean leaves sprayed with Th17 showed increased activities of lignification-related and antioxidative enzymes and their isoforms (Jung et al., 2008a; Lee et al., 2009b); this constituted the first report of plant growth stimulation by a bacteriocin. Recent research on Th17 has highlighted its plant growth promotion and abiotic stress alleviation properties. It was found that at $24 \mathrm{~h}$ after exposure to Th17, Arabidopsis thaliana Col-0 rosettes showed decreased levels of cytokinins, gibberellins, JA, and ABA; and an increase in IAA $(85.39 \%)$ and SA $(42.21 \%)$ as compared to untreated control plants. A. thaliana responded positively to treatment with Th17 in the presence of salt stress (up to $250 \mathrm{mM} \mathrm{NaCl}$ ). Shotgun proteomics of unstressed and $250 \mathrm{mM} \mathrm{NaCl}$ stressed A. thaliana rosettes ( 7 days post stress) in combination with Th17 revealed carbon and energy metabolic pathways being affected under both unstressed and salt stressed conditions. Chloroplast proteins and proteins of photosystem I and II that are generally strongly and negatively affected by salt stress and PEP carboxylase, Rubisco-oxygenase large subunit, and pyruvate kinase, were some of the noteworthy proteins enhanced ( $>2$-fold changes in the activation of the carbon and energy metabolism pathway) by Th17 application, along with other stress related proteins. These findings suggest that the proteome of $A$. thaliana rosettes is altered by the bacterial signal, and more so under salt stress, thereby imparting a positive effect on plant growth under high salt stress (Subramanian, 2014).

Application of Th17, under water stress conditions, to 1 month-old soybean plants increased plant biomass by $17 \%$, root biomass by $37 \%$ and root nodule biomass by $55 \%$, and also the amount of abscisic acid in soybean roots by $30 \%$ (Prudent et al., 2014). Application of Th17 to soybean seeds (variety Absolute RR) caused accelerated seed germination under salt stress of up to $150 \mathrm{mM} \mathrm{NaCl}$, with the best response seen at $100 \mathrm{mM} \mathrm{NaCl}$. Shotgun proteomics of unstressed and $100 \mathrm{mM}$ $\mathrm{NaCl}$ stressed seeds $(48 \mathrm{~h})$ in combination with Th17 revealed that carbon, nitrogen and energy metabolic pathways were affected under both unstressed and salt stressed conditions. PEP carboxylase, Rubisco oxygenase large subunit, pyruvate kinase, alcohol dehydrogenase, and isocitrate lyase were some of the noteworthy proteins enhanced ( $>2$-fold changes), by the signal, along with antioxidant glutathione- $S$-transferase and other stress related proteins. The up-regulation of PEP carboxylase and a marked down-regulation of $\alpha$ - and $\beta$-subunits of conglycinin, glycinin, as compared to the control treatment, is indicative of efficient storage protein utilization in conjunction with thioredoxin. These findings suggest that the germinating seeds alter their proteome based on bacterial signals and on stress level; the specificity of this response plays a crucial role in organ maturation and transition from one stage to another in a plant's life cycle; understanding this response is of fundamental importance in agriculture and, as a result, global food security (Subramanian, 2014). As observed in our experiments, the effective concentration of bacteriocin for enhanced plant growth and production is in the order of nanomolar $\left(10^{-9} \mathrm{M}\right)$, which makes it economically viable as method to decrease the use of energy based fertilizers and chemicals used in agricultural crop production systems.

\section{BACTERIOCINS IN THE VETERINARY INDUSTRY AND HUMAN MEDICINE}

Bacteriocins from $B$. thuringiensis also have proven to be of importance in veterinary medicine. S. aureus causes clinical and subclinical bovine mastitis, which is difficult to treat due to increased frequency of resistance to antimicrobial agents. S. aureus isolates recovered from milk composite samples of Holstein lactating cows in Mexico were evaluated for susceptibility of the isolates to 12 antibiotics and five bacteriocins from B. thuringiensis. S. aureus isolates were resistant to penicillin (92\%), dicloxacillin (86\%), ampicillin (74\%), and erythromycin (74\%) and susceptible to gentamicin (92\%), trimethoprim (88\%) and tetracycline (72\%). S. aureus isolates also showed susceptibility to the five bacteriocins synthesized by $B$. thuringiensis, morricin 269 and kurstacin 287 followed by kenyacin 404, entomocin 420 and tolworthcin 524 suggesting an alternate method of controlling bovine mastitis (Barboza-Corona et al., 2009).

Mexican strains of $B$. thuringiensis, B. thuringiensis ssp. morrisoni (LBIT 269), B. thuringiensis ssp. kurstaki (LBIT 287), B. thuringiensis ssp. kenyae (LBIT 404), B. thuringiensis ssp. entomocidus (LBIT 420) and B. thuringiensis ssp. tolworthi (LBIT 524) produce proteinaceous Bt-BLIS bactericidal activities against B. cereus and Vibrio cholera (Barboza-Corona et al., 2007) but had no effect against Gram-negative bacteria such as Escherichia coli, Shigella species, and P. aeruginosa, all of which are human pathogens. Entomocin 9 was found to be bactericidal to Listeria monocytogenes, pathogenic P. aeruginosa and several fungi causing cell lysis of growing cells and nontoxic to Vero cells (Cherif et al., 2003). Thuricin 439, however, is a narrow spectrum bacteriocin capable of affecting growth of B. cereus (Ahern et al., 2003), while thuricin S is anti-Listeria (Chehimi et al., 2007) and a pore-forming bacteriocin (Chehimi et al., 2010). B. cereus cells protect themselves from Enterocin AS-48 produced by Enterococcus faecalis S48 by up-regulating the 
BC4207 membrane protein for probable membrane structure modulation (Burgos et al., 2009). While pyocins produced by $P$. aeruginosa strains have proven to be toxic by degrading DNA in sensitive bacterial cells (Parret and De Mot, 2002). B. subtilis strain LFB112 from Chinese herbs produces a $6.3 \mathrm{kDa}$ bacteriocin that is effective against E. coli, Salmonella pullorum, $P$. aeruginosa, Pasteurella multocida, Clostridium perfringens, Micrococcus luteus, Streptococcus bovis, and S. aureus IVDC C56005, all of which are common domestic animal related pathogens (Xie et al., 2009).

Optimizing medium composition, incubation and agitation speed can result in enhancement of the production of some bacteriocins. For example, B. thuringiensis subsp. kurstaki strain, producing the bacteriocin Bacthuricin F4 when grown in TSB medium with an optimal carbon-nitrogen ratio of 9 increases the bacteriocin production fourfold (Kamoun et al., 2009). Bacteriocin Bacillus sp. YAS 1 could be increased 1.6-fold by this method. This bacteriocin had a wide $\mathrm{pH}$ range (1-13) as well as temperature $\left(45-80^{\circ} \mathrm{C}\right)$ with antimicrobial activity to human pathogens such as Clostridium, Staphylococcus, Enterococcus, and Salmonella, and plant pathogens such as E. amylovora, and showing no effect on lactic acid bacteria (Embaby et al., 2014).

\section{BACTERIOCINS FROM OTHER INTERESTING BACTERIAL SOURCES}

While most bacteriocins we know today have been isolated from the rhizosphere bacteria, bacteria producing bacteriocins are wide spread. A B. subtilis strain isolated from a Chinese fermented seasoning produces a $3.4 \mathrm{kDa}$ bacteriocin that is active against $B$. cereus and $L$. monocytogenes (Zheng and Slavik, 1999). Maari, an alkaline fermented food condiment made from baobab tree seeds, is comprised of several strains of B. subtilis, all of which are necessary for enhancing the flavor and texture of the product. Three B. subtilis strains (B3, B122, and B222) isolated from maari produced bacteriocins that had antibacterial activities against $B$. cereus NVH391-98, a common opportunist

\section{REFERENCES}

Abriouel, H., Franz, C. M., Omar, N. B., and Gálvez, A. (2011). Diversity and applications of Bacillus bacteriocins. FEMS Microbiol. Rev. 35, 201-232. doi: 10.1111/j.1574-6976.2010.00244.x

Ahern, M., Verschueren, S., and van Sinderen, D. (2003). Isolation and characterisation of a novel bacteriocin produced by Bacillus thuringiensis strain B439. FEMS Microbiol. Lett. 220, 127-131. doi: 10.1016/S0378-1097(03)00086-7

Ahmad, V., Iqbal, A. N., Haseeb, M., and Khan, M. S. (2014). Antimicrobial potential of bacteriocin producing Lysinibacillus jx416856 against food borne bacterial and fungal pathogens, isolated from fruits and vegetable waste. Anaerobe 27, 87-95. doi: 10.1016/j.anaerobe.2014.04.001

Bai, Y., Souleimanov, A., and Smith, D. L. (2002b). An inducible activator produced by a Serratia proteamaculans strain and its soybean growthpromoting activity under greenhouse conditions. J. Exp. Bot. 373, 1495-1502. doi: 10.1093/jexbot/53.373.1495

Bai, Y., Zhou, X., and Smith, D. L. (2003). Enhanced soybean plant growth resulting from co-inoculation of Bacillus strains with Bradyrhizobium japonicum. Crop Sci. 43, 1774-1781. doi: 10.2135/cropsci2003.1774

Barboza-Corona, J. E., de la Fuente-Salcido, J. E. N., Alva-Murillo, N., OchoaZarzosa, A., and Lòpez-Meza, J. E. (2009). Activity of bacteriocins synthesized human pathogen that contaminates maari (Kaboré et al., 2013). People in Burkina Faso and neighboring countries consume a fermented product called bilakga, derived from the seeds of Hibiscus sabdariffa. The fermentation concoction is largely comprised of B. subtilis subsp. subtilis and Bacillus licheniformis isolates. PCR detection of genes coding for surfactins and plipastatins (fengycins) suggested the production of subtilosin, subtilin and lipopeptide, while a protein (a probable bacteriocin) with a mass of $3.347 \mathrm{kDa}$ was also isolated (Compaoré et al., 2013). B. thuringiensis ssp. kurstaki Bnl isolated from hazel nut pest Balaninus nucum L. produces a bacteriocin Bt-Bn1, the first of its kind of insect origin. Like its potential commercial counterparts, this bacteriocin has antibacterial activity against $B$. cereus, $P$. syringae, and $P$. lemoignei, and other $B$. thuringiensis strains (Ugras et al., 2013).

\section{CONCLUSION}

Excessive use of fertilizers and other chemicals in agriculture and multi-drug resistant microbes are two major challenges for scientists worldwide. Bacteriocins evaluated as plant growth promotors and those with disease suppression mechanisms are a viable option for efficient use in agriculture, to reduce the use of fertilizers and chemical inputs such as fungicides and insecticides. With respect to multi-drug resistance, bacteriocins can be interesting in commercial utilization as target proteins for replacing ineffective antibiotics or for combinatorial drug therapy both in veterinary and human medicine, apart from their use in food preservation.

\section{FUNDING}

The authors wish to acknowledge support from the NSERC strategic Green Crop Network, from the Eastern Canadian Oilseed Development Alliance ECODI network and from the NCE funded BioFuelNet Canada.

by Bacillus thuringiensis against Staphylococcus aureus isolates associated to bovine mastitis. Vet. Microbiol. 138, 179-183. doi: 10.1016/j.vetmic.2009. 03.018

Barboza-Corona, J. E., Vázquez-Acosta, H., Bideshi, D. K., and SalcedoHernández, R. (2007). Bacteriocin-like inhibitor substances produced by Mexican strains of Bacillus thuringiensis. Arch. Microbiol. 187, 117-126.

Beegle, C. C., and Yamamoto, T. (1992). Invitation paper (C.P. Alexander Fund): history of Bacillus thuringiensis berliner research and development. Can. Entomol. 124, 587-616. doi: 10.4039/Ent124587-4

Bizani, D., Motta, A. S., Morrissy, J. A. C., Terra, R. M. S., Souto, A. A., and Brandelli, A. (2005). Antibacterial activity of cerein 8A, a bacteriocin-like peptide produced by Bacillus cereus. Int. Microbiol. 8, 125-131.

Burgos, M. J. G., Kovács, A. T., Miroñczuk, A. M., Abriouel, H., Gálvez, A., and Kuipers, O. P. (2009). Response of Bacillus cereus ATCC 14579 to challenges with sublethal concentrations of enterocin AS-48. BMC Microbiol. 9:227. doi: 10.1186/1471-2180-9-227

Chattopadhyay, A., Bhatnagar, N. B., and Bhatnagar, R. (2004). Bacterial insecticidal toxins. Crit. Rev. Microbiol. 30, 33-54. doi: 10.1080/10408410 490270712

Chehimi, S., Delalande, F., Sablè, S., Hajlaoui, M.-R., Van Dorsselaer, A., Limam, F., et al. (2007). Purification and partial amino acid sequence of thuricin S, a 
new anti-Listeria bacteriocin from Bacillus thuringiensis. Can. J. Microbiol. 53, 284-290. doi: 10.1139/w06-116

Chehimi, S., Pons, A.-M., Sablè, S., Hajlaoui, M.-R., and Limam, F. (2010). Mode of action of thuricin S, a new class IId bacteriocin from Bacillus thuringiensis. Can. J. Microbiol. 56, 162-167. doi: 10.1139/w09-125

Cherif, A., Chehimi, S., Limem, F., Hansen, B. M., Hendriksen, N. B., Daffonchio, D., et al. (2003). Detection and characterization of the novel bacteriocin entomocin 9, and safety evaluation of its producer, Bacillus thuringiensis ssp. entomocidus HD9. J. Appl. Microbiol. 95, 990-1000.

Cherif, A., Quazri, H., Daffonchio, D., Cherif, H., Ben Slama, K., Hassen, A., et al. (2001). Thuricin 7: a novel bacteriocin produced by Bacillus thuringenesis BMG 1.7, a new strain isolated from soil. Lett. Appl. Microbiol. 32, 243-247. doi: 10.1046/j.1472-765X.2001.00898.x

Cherif, A., Rezguia, W., Raddadi, N., Daffonchio, D., and Boudabous, A. (2008). Characterization and partial purification of entomocin110, a newly identified bacteriocin from Bacillus thuringiensis subsp. Entomocidus HD110. Microbiol. Res. 163, 684-692. doi: 10.1016/j.micres.2006.10.005

Compaoré, C. S., Nielsen, D. S., Ouoba, L. I. I., Berner, T. B., Nielsen, K. F., Sawadogo-Lingani, H., et al. (2013). Co-production of surfactin and a novel bacteriocin by Bacillus subtilis subsp. Subtilis H4 isolated from Bikalga, an African alkaline Hibiscus sabdariffa seed fermented condiment. Int. J. Food Microbiol. 162, 297-307. doi: 10.1016/j.ijfoodmicro.2013.01.013

Daw, M. A., and Falkiner, F. R. (1996). Bacteriocins: nature. Funct. Struct. Micron. 27, 467-479.

de Freire Bastos, M. C., Coelho, M. L. V., and da Silva Santos, O. C. (2015). Resistance to bacteriocins produced by Gram-positive bacteria. Microbiology 161, 683-700. doi: 10.1099/mic.0.082289-0

de la Fuente-Salcido, N., Alanís-Guzmán, M. G., Bideshi, D. K., SalcedoHernández, R., Bautista-Justo, M., and Barboza-Corona, J. E. (2008). Enhanced synthesis and antimicrobial activities of bacteriocins produced by Mexican strains of Bacillus thuringiensis. Arch. Microbiol. 190, 633-640. doi: 10.1007/s00203-008-0414-2

de la Fuente-Salcido, N. M., Casados-Vázquez, L. E., and Barboza-Corona, J. E. (2013). Bacteriocins of Bacillus thuringiensis can expand the potential of this bacterium to other areas rather than limit its use only as microbial insecticide. Can. J. Microbiol. 59, 515-522. doi: 10.1139/cjm-2013-0284

Embaby, A. M., Heshmat, Y., Hussein, A., and Marey, H. S. (2014). A sequential statistical approach towards an optimized production of a broad spectrum bacteriocin substance from a soil bacterium Bacillus sp. YAS 1 strain. Sci. World J. 2014:396304. doi: 10.1155/2014/396304

Favret, M. E., and Yousten, A. A. (1989). Thuricin: the bacteriocin produced by Bacillus thuringiensis. J. Invertebr. Pathol. 53, 206-216. doi: 10.1016/00222011(89)90009-8

Feil, H., Feil, W. S., Chain, P., Larimer, F., DiBartolo, G., Copeland, A., et al. (2005). Comparison of the complete genome sequences of Pseudomonas syringae pv. syringae B728a and pv. tomato DC3000. Proc. Natl. Acad. Sci. U.S.A. 102, 11064-11069. doi: 10.1073/pnas.0504930102

Gray, E. J., Di Falco, M., Souleimanov, A., and Smith, D. L. (2006a). Proteomic analysis of the bacteriocin, Thuricin-17 produced by Bacillus thuringiensis NEB17. FEMS Microbiol. Lett. 255, 27-32. doi: 10.1111/j.15746968.2005.00054.x

Gray, E. J., Lee, K., Di Falco, M., Souleimanov, A., Zhou, X., and Smith, D. L. (2006b). A novel bacteriocin, thuricin 17, produced by PGPR strain Bacillus thuringiensis NEB17: isolation and classification. J. Appl. Microbiol. 100, 545554. doi: 10.1111/j.1365-2672.2006.02822.x

Hammami, I., Rhouma, A., Jaouadi, B., Rebai, A., and Nesme, X. (2009). Optimization and biochemical characterization of a bacteriocin from a newly isolated Bacillus subtilis strain 14B for biocontrol of Agrobacterium spp. strains. Lett. Appl. Microbiol. 48, 253-260. doi: 10.1111/j.1472-765X.2008.02524.x

Hammami, I., Triki, M. A., and Rebai, A. (2011). Purification and characterization of the novel bacteriocin IH7 with antifungal and antibacterial properties. J. Plant Pathol. 93, 443-454.

Holtsmark, I., Eijsink, V. G. H., and Brurberg, M. B. (2008). Bacteriocins from plant pathogenic bacteria. FEMS Microbial. Lett. 280, 1-7. doi: 10.1111/j.15746968.2007.01010.x

Holtsmark, I., Mantzilas, D., Eijsink, V. G. H., and Brurberg, M. B. (2006). Purification, characterization, and gene sequence of michiganin $\mathrm{A}$, an actagardine-like lantibiotic produced by the tomato pathogen Clavibacter michiganensis subsp. Michiganensis. Appl. Environ. Microbiol. 72, 5814-5821. doi: 10.1128/AEM.00639-06

Ibrahim, M. A., Griko, N., Junker, M., and Bulla, L. A. (2010). Bacillus thuringiensis - A genomics and proteomics perspective. Bioeng. Bugs 1, 31-50. doi: 10.4161/bbug.1.1.10519

Jabeen, N., Rasool, S. A., Ahmad, S., Ajaz, M., and Saeed, S. (2004). Isolation, identification and bacteriocin production by indigenous diseased plant and soil associated bacteria. Pakistan J. Biol. Sci. 7, 1893-1897. doi: 10.3923/pjbs.2004.1893.1897

Jack, R. W., Tagg, J. R., and Ray, B. (1995). Bacteriocins of gram-positive bacteria. Microbiol. Rev. 59, 171-200.

Jung, W., Mabood, F., Souleimanov, A., Zhou, X., Jaoua, S., Kamoun, F., et al. (2008a). Stability and antibacterial activity of bacteriocins produced by Bacillus thuringiensis and Bacillus thuringiensis ssp. Kurstaki. J. Microbiol. Biotechnol. 18, 1836-1840.

Kaboré, D., Nielsen, D. S., Sawadogo-Lingani, H., Diawara, B., Dicko, M. H., Jakobsen, M., et al. (2013). Inhibition of Bacillus cereus growth by bacteriocin producing Bacillus subtilis isolated from fermented baobab seeds (maari) is substrate dependent. Int. J. Food Microbiol. 162, 114-119. doi: 10.1016/j.ijfoodmicro.2012.12.027

Kamoun, F., Ben Fguira, I., Ben Hassen, N. B., Mejdoub, H., Lereclus, D., and Jaoua, S. (2011). Purification and characterization of a new Bacillus thuringiensis bacteriocin active against Listeria monocytogenes, Bacillus cereus and Agrobacterium tumefaciens. Appl. Biochem. Biotechnol. 165, 300-314. doi: 10.1007/s12010-011-9252-9

Kamoun, F., Mejdoub, H., Aouissaoui, H., Reinbolt, J., Hammami, A., and Jaoua, S. (2005). Purification, amino acid sequence and characterization of Bacthuricin F4, a new bacteriocin produced by Bacillus thuringiensis. J. Appl. Microbiol. 98, 881-888. doi: 10.1111/j.1365-2672.2004.02513.x

Kamoun, F., Zouari, F. N., Saadaoui, I., and Jaoua, S. (2009). Improvement of Bacillus thuringiensis bacteriocin production through culture conditions optimization. Prep. Biochem. Biotechnol. 39, 400-412. doi: 10.1080/10826060903209653

Klaenhammer, T. (1993). Genetics of bacteriocins produced by lactic acid bacteria. FEMS Microbiol. Lett. 12, 39-86. doi: 10.1016/0168-6445(93)90057-G

Lee, H., Churey, J. J., and Worobo, R. W. (2009a). Biosynthesis and transcriptional analysis of thurincinH, a tandem repeated bacteriocin genetic locus, produced by Bacillus thuringiensis SF361. FEMS Microbiol. Lett. 299, 205-213. doi: 10.1111/j.1574-6968.2009.01749.x

Lee, K., Gray, E. J., Mabood, F., Jung, W., Charles, T., Clark, S. R. D., et al. (2009b). The class IId bacteriocin thuricin-17 increases plant growth. Planta 229, 747-755. doi: 10.1007/s00425-008-0870-6

Lotz, W., and Mayer, F. (1972). Isolation and characterization of a bacteriophage tail-like bacteriocin from a strain of Rhizobium. J. Virol. 9, 160-173.

Mouloud, G., Daoud, H., Bassem, J., Atef, I. L., and Hani, B. (2013). New bacteriocin from Bacillus clausii strainGM17: purification, characterization, and biological activity. Appl. Biochem. Biotechnol. 171, 2186-2200. doi: 10.1007/s12010-013-0489-3

Olasupo, N. N., Fitzgerald, D. J., Gasson, M. J., and Narbad, A. (2003). Activity of natural antimicrobial compounds against Escherichia coli and Salmonella enterica serovar typhimurium. Lett. Appl. Microbiol. 37, 448-451. doi: 10.1046/j.1472-765X.2003.01427.x

Oscáriz, J. C., Lasa, I., and Pisabarro, A. G. (1999). Detection and characterization of cerein 7, a new bacteriocin produced by Bacillus cereus with a broad spectrum of activity. FEMS Microbiol. Lett. 178, 337-341. doi: 10.1016/S03781097(99)00370-5

Paik, H. D., Bae, S. S., Park, S. H., and Pan, J. G. (1997). Identification and partial characterization of tochicin, a bacteriocin produced by Bacillus thuringiensis subsp tochigiensis. J. Ind. Microbiol. Biotechnol. 19, 294-298. doi: 10.1038/sj.jim.2900462

Palma, L., Muñoz, D., Berry, C., Murillo, J., and Caballero, P. (2014). Bacillus thuringiensis toxins: an overview of their biocidal activity. Toxins 6, 3296-3325. doi: $10.3390 /$ toxins6123296

Parret, A. H. A., and De Mot, R. (2002). Bacteria killing their own kind: novel bacteriocins of Pseudomonas and other $\gamma$-proteobacteria. Trends Microbiol. 10, 107-112. doi: 10.1016/S0966-842X(02)02307-7

Parret, A. H. A., Schoofs, G., Proost, P., and De Mot, R. (2003). Plant lectin-like bacteriocin from a rhizosphere-colonizing Pseudomonas 
isolate. J. Bacteriol. 185, 897-908. doi: 10.1128/JB.185.3.897908.2003

Pfister, H., and Lodderstaedt, G. (1977). Adsorption of a phage tail-like bacteriocin to isolated lipopolysaccharide of Rhizobium. J. Gen. Virol. 37, 337-347. doi: 10.1099/0022-1317-37-2-337

Prudent, M., Salon, C., Souleimanov, A., Emery, R. J. N., and Smith, D. L. (2014). Soybean is less impacted by water stress using Bradyrhizobium japonicum and thuricin-17 from Bacillus thuringiensis. Agron. Sustain. Dev. 35, 749-757. doi: 10.007/s13593-014-0256-z

Pugsley, A. P. (1984). The ins and outs of colicins. II. Lethal action, immunity and ecological implications. Microbiol. Sci. 1, 203-205.

Raddadi, N., Belaouis, A., Tamagnini, I., Hansen, B. M., Hendriksen, N. B., Boudabous, A., et al. (2009). Characterization of polyvalent and safe Bacillus thuringiensis strains with potential use for biocontrol. J. Basic Microbiol. 49, 293-303. doi: 10.1002/jobm.200800182

Rea, M. C., Sit, C. S., Clayton, E., O’Connor, P. M., Whittal, R. M., Zheng, J., et al. (2010). Thuricin CD, a posttranslationally modified bacteriocin with a narrow spectrum of activity against Clostridium difficile. Proc. Natl. Acad. Sci. U.S.A. 107, 9352-9357. doi: 10.1073/pnas.0913554107

Riley, M. A. (1998). Molecular mechanisms of bacteriocin evolution. Annu. Rev. Genet. 32, 255-278. doi: 10.1146/annurev.genet.32.1.255

Schnepf, E., Crickmore, N., Van Rie, J., Lereclus, D., Baum, J., Feitelson, J., et al. (1998). Bacillus thuringiensis and its pesticidal crystal proteins. Microbiol. Mol. Biol. Rev. 62, 775-806.

Scholz, R., Vater, J., Budiharjo, A., Wang, Z., He, Y., Dietel, K., et al. (2014). Amylocyclicin, a novel circular bacteriocin produced by Bacillus amyloliquefaciens FZB42. J. Bacteriol. 196, 1842-1852. doi: 10.1128/JB.01474-14

Smitha, S., and Bhat, S. G. (2012). Thermostable bacteriocin BL8 from Bacillus licheniformis isolated from marine sediment. J. Appl. Microbiol. 114, 688-694. doi: $10.1111 /$ jam. 12097
Subramanian, S. (2014). Mass Spectrometry Based Proteome Profiling to Understand the Effects of Lipo-Chito-Oligosaccharide and Thuricin 17 in Arabidopsis thaliana and Glycine max Under Salt Stress. Ph.D. thesis, McGill University, Montreal, QC.

Tagg, J., Daiani, A., and Wannamaker, L. (1976). Bacteriocins of gram-positive bacteria. Bacteriol. Rev. 40, 722-756.

Ugras, S., Sezen, K., Kati, H., and Demirbag, Z. (2013). Purification and characterization of the bacteriocin Thuricin Bn1 produced by Bacillus thuringiensis subsp. kurstaki Bn1 isolated from a hazelnut pest. J. Microbiol. Biotechnol. 23, 167-176. doi: 10.4014/jmb.1209. 09056

Xie, J., Zhang, R., Shang, C., and Guo, Y. (2009). Isolation and characterization of a bacteriocin produced by an isolated Bacillus subtilis LFB112 that exhibits antimicrobial activity against domestic animal pathogens. Afr. J. Biotechnol. 8, 5611-5619.

Zheng, G., and Slavik, M. F. (1999). Isolation, partial purification and characterization of a bacteriocin produced by a newly isolated Bacillus subtilis strain. Lett. Appl. Microbiol. 28, 363-367. doi: 10.1046/j.1365-2672.1999. 00545.x

Conflict of Interest Statement: The authors declare that the research was conducted in the absence of any commercial or financial relationships that could be construed as a potential conflict of interest.

Copyright (c) 2015 Subramanian and Smith. This is an open-access article distributed under the terms of the Creative Commons Attribution License (CC BY). The use, distribution or reproduction in other forums is permitted, provided the original author(s) or licensor are credited and that the original publication in this journal is cited, in accordance with accepted academic practice. No use, distribution or reproduction is permitted which does not comply with these terms. 